\title{
Campylobacters and impaired fetal development in mice
}

\author{
A. M. O'SULLIVAN, C. J. DORÉ* and C. R. COID
}

Divisions of Comparative Medicine and "Medical Statistics, Clinical Research Centre, Harrow HA1 3UJ

\begin{abstract}
Summary. Intravenous injection of eight human strains of Campylobacter fetus ss fetus and Campylobacter jejuni into mice at various stages of pregnancy demonstrated significant strain differences in ability to affect implantation of the fertilised ovum and to cause resorption of the mouse fetus. Implantation was significantly impaired when $C$. fetus ss fetus was injected intravenously on day 2 of pregnancy, but no effect was observed in mice receiving $C$. jejuni. On day 6 of pregnancy, before the development of placental circulation, both $C$. fetus ss fetus and $C$. jejuni impaired fetal growth; one strain of $C$. jejuni had a greater effect than others of the same species. In animals inoculated on day 13 of pregnancy, after the development of placental circulation, six of the eight campylobacter strains caused resorption of the mouse embryos. A similar effect on the embryos was observed after injection of heat-killed organisms, and endotoxin-like substances may have been responsible. It is also suggested that factors other than endotoxin-like substances have a deleterious effect on embryonic growth.
\end{abstract}

\section{Introduction}

In the past decade campylobacters have emerged as important pathogens of man. Of the three species known to be associated with human disease, twoCampylobacter jejuni and C. coli-are among the most common causes of infectious diarrhoea (Skirrow, 1977), whereas C. fetus ss fetus (henceforth referred to as $C$. fetus) is recognised as a cause of septicaemia in immunocompromised hosts (Guerrant et al., 1978). Campylobacters can also cause enteric infections in animals, but infertility and abortion are more common (Coid and Fox, 1983).

Human infection was first described by Vinzent et al. (1947) in a pregnant woman, who had a bacteriaemia caused by $C$. fetus, and who subsequently aborted at 6 months' gestation. Since then, at least 20 cases of abortion and perinatal sepsis associated with campylobacter infection have been reported (Simor et al., 1986), C.fetus being identified in ten cases, $C$. jejuni in nine, and $C$. coli in one.

Severe systemic disturbances during pregnancy can be caused by endotoxins from gram-negative bacteria. For example, Escherichia coli endotoxin impairs fetal development in the mouse (Coid, 1976), and in many other species endotoxins have an abortifacient effect (Dennis, 1967). Because purified lipopolysaccharide from $C$. jejuni is similar to that from Enterobacteriaceae (Naess and Hof-

Received 18 Dec. 1986; accepted 4 Mar. 1987. stad, 1982), the present investigations were undertaken to determine whether campylobacters have a deleterious effect on fetal development, similar to that produced by endotoxins from other bacterial sources.

\section{Materials and methods}

\section{Campylobacter strains}

The four $C$. fetus strains were kindly supplied by Dr M. B. Skirrow and the four $C$. jejuni strains by the Microbiology Department of Northwick Park Hospital. All came from human patients and were subcultured three times in this laboratory before use. Stock cultures were maintained at $-70^{\circ} \mathrm{C}$. The C. fetus strains comprised: nos. 3329 and 25320, isolated from blood; no. 23907 , from an ovarian abscess; and no. 613 , from a wound. The $C$. jejuni strains comprised: no. 42734, isolated from the watery faeces of a 77-year-old female with osteomyelitis; no. 43353, from the watery faeces of a 20 -year old male; no. 39175 , from the blood-stained faeces of a 30-year old female; and no. 40630, from the blood-stained faeces of a 26-year old male. Each suspension for injection was prepared by inoculating $10 \mathrm{ml}$ of Brucella Broth (Difco) with $0.1 \mathrm{ml}$ of stock culture and incubating at $37^{\circ} \mathrm{C}$ in a micro-aerophilic environment produced by means of a Campypack (Oxoid). Broth cultures incubated for $30 \mathrm{~h}$ were diluted 1 in 4 in sterile medium to give an overall median infecting dose of $1.3 \times 10^{9}$ colony-forming units (cfu)/mouse, the interquartile range $(\mathrm{IQR})$ being $(1-5 \cdot 1) \times 10^{9}$. Heat-killed 
suspensions of campylobacters were prepared by heating the inocula in a water bath at $63^{\circ} \mathrm{C}$ for $45 \mathrm{~min}$.

\section{Estimation of the number of campylobacters in mouse tissues}

The method (Coid and Nicholson, 1981) was briefly as follows. At the termination of each experiment the mice were killed by dislocation of the cervical vertebrae. The abdomen was opened aseptically and the spleen and liver were removed, dipped in $80 \%$ alcohol, and flamed. Each uterus was dissected separately and the placentae and fetuses were removed and transferred to sterile containers. The tissues were homogenised in brucella broth, and the number of campylobacters in each organ was calculated from the number of colonies growing on blood-agar plates after spreading $0 \cdot 1-\mathrm{ml}$ volumes of appropriate dilutions and incubating for $48 \mathrm{~h}$ in a micro-aerophilic environment.

\section{Mice}

Female mice of an outbred strain (TO/Crc) aged 10 weeks were obtained from the specific pathogen-free breeding unit at this Centre. The first day of pregnancy was taken to be that on which the vaginal plug was observed. Individual mice were given $0.2 \mathrm{ml}$ of the inoculum intravenously in the tail. The test groups received a Campylobacter sp. and the control groups sterile brucella broth.

\section{Estimation of the number of resorptions in mice}

All experiments were terminated on the eighteenth day of gestation. Immediately after the mice were killed, their abdomens were aseptically opened. The uterus was then removed and opened to reveal the number of resorbed and healthy fetuses. The ovaries were also removed from those mice inoculated on day 2 of pregnancy.

To obtain the number of pre-implantation deaths in the group of mice inoculated on day 2 of pregnancy, the differences between the corpora luteal counts and the total numbers of live and dead implants were taken.

\section{Statistical methods}

Mann-Whitney U tests were used to compare groups for both the proportion of resorptions (ratio of resorptions to the total number of live and dead fetuses) and the proportion of pre-implantation loss (ratio of pre-implantation deaths to the total number of live and dead implants).

\section{Results}

\section{The effect of Campylobacter spp. on 2-day pregnant mice}

To determine the effect of $C$. fetus and $C$. jejuni on implantation of the fertilised ovum, 2-day pregnant mice were given inocula of the campylobacters intravenously. Combining results for all $C$. fetus strains, there was a significant effect $(\mathrm{p}=0.005)$ on pre-implantation loss of the fetus, whereas the C. jejuni strains combined had no such effect $(\mathrm{p}=0.35)$ (table I). No differences could be demonstrated between the effects of individual strains within each species tested.

Table I. The effect of a median dose of $1.6 \times 10^{9}$ campylobacters on the pre-implantation loss of the 2-day mouse fetus

\begin{tabular}{|c|c|c|c|c|c|c|c|c|}
\hline \multirow{2}{*}{$\begin{array}{l}\text { Campylobacter sp. } \\
\text { and strain }\end{array}$} & \multirow[b]{2}{*}{ Origin } & \multirow{2}{*}{$\begin{array}{l}\text { Number } \\
\text { of mice }\end{array}$} & \multicolumn{2}{|c|}{$\begin{array}{l}\text { Pre-implantation loss in } \\
\text { control mice }\end{array}$} & \multirow{2}{*}{$\begin{array}{l}\text { Number } \\
\text { of mice }\end{array}$} & \multicolumn{2}{|c|}{$\begin{array}{l}\text { Pre-implantation loss } \\
\text { in infected mice }\end{array}$} & \multirow[b]{2}{*}{$\mathrm{p}$ Value } \\
\hline & & & Median & IQR & & Median & IQR & \\
\hline \multicolumn{9}{|l|}{ C. fetus } \\
\hline 25320 & blood & 3 & 0.08 & $0-0 \cdot 20$ & 4 & $0 \cdot 16$ & $0 \cdot 09-0 \cdot 24$ & $0 \cdot 22$ \\
\hline 23907 & ovarian abscess & 3 & 0 & $0-0 \cdot 14$ & 7 & $0 \cdot 18$ & $0-0.33$ & $0 \cdot 25$ \\
\hline 3329 & blood & 4 & 0.04 & $0-0.08$ & 5 & $0 \cdot 21$ & $0-0 \cdot 40$ & $0 \cdot 11$ \\
\hline 613 & wound & 6 & 0 & $0-0.03$ & 5 & $0 \cdot 10$ & $0-0 \cdot 13$ & 0.32 \\
\hline $\begin{array}{l}\text { All C. fetus } \\
\text { strains }\end{array}$ & & 16 & 0 & $0-0 \cdot 08$ & 21 & $0 \cdot 13$ & $0.05-0 \cdot 27$ & 0.005 \\
\hline \multicolumn{9}{|l|}{ C. jejuni } \\
\hline 42734 & faeces & 5 & $0 \cdot 15$ & $0-0 \cdot 18$ & 4 & 0 & $0-0$ & $0 \cdot 18$ \\
\hline 43353 & faeces & 3 & $0 \cdot 15$ & $0-0.25$ & 3 & $0 \cdot 11$ & $0-0 \cdot 17$ & 0.83 \\
\hline 39175 & faeces & 4 & 0 & $0-0 \cdot 12$ & 3 & 0 & $0-0$ & 0.72 \\
\hline 40630 & faeces & 5 & 0 & $0-0 \cdot 17$ & 3 & 0.09 & $0-0 \cdot 20$ & $0 \cdot 65$ \\
\hline $\begin{array}{l}\text { All } C . \text { jejuni } \\
\text { strains }\end{array}$ & & 17 & 0 & $0-0 \cdot 16$ & 13 & 0 & $0-0 \cdot 10$ & $0 \cdot 35$ \\
\hline
\end{tabular}

$\mathrm{IQR}=$ interquartile range. 
The effect of Campylobacter spp. on 6-day pregnant mice

When 6-day pregnant mice were inoculated with campylobacters, the overall results (table II) showed a significant difference in the proportion of resorbed fetuses between the $C$. jejuni treated group, and the control group $(p=0.02)$, and when each strain was considered separately there was a significant difference for strain $42734(p=0 \cdot 01)$. C. fetus was shown to have impaired the development of the 6-day mouse fetus $(p=0 \cdot 05)$ when all strain data were combined, but there were no significant differences between individual strains.

The effect of Campylobacter spp. on 13-day pregnant mice

When compared with the control group, animals inoculated with live campylobacters on day 13 of pregnancy showed an increase in the proportion of fetuses resorbed as a result of inoculation with all four strains of $C$. fetus and with two of the four strains of $C$. jejuni (table III).

Table II. The effect of a median dose of $1.2 \times 10^{9}$ campylobacters on the development of the 6-day mouse fetus

\begin{tabular}{|c|c|c|c|c|c|c|c|c|}
\hline \multirow{2}{*}{$\begin{array}{l}\text { Campylobacter sp. } \\
\text { and strain }\end{array}$} & \multirow[b]{2}{*}{ Origin } & \multirow{2}{*}{$\begin{array}{l}\text { Number } \\
\text { of mice }\end{array}$} & \multicolumn{2}{|c|}{$\begin{array}{l}\text { Proportion of resorptions in } \\
\text { control mice }\end{array}$} & \multirow{2}{*}{$\begin{array}{l}\text { Number } \\
\text { of mice }\end{array}$} & \multicolumn{2}{|c|}{$\begin{array}{l}\text { Proportion of resorptions in } \\
\text { infected mice }\end{array}$} & \multirow[b]{2}{*}{$\mathrm{p}$ value } \\
\hline & & & Median & IQR & & Median & IQR & \\
\hline \multicolumn{9}{|l|}{ C. fetus } \\
\hline 25320 & blood & 9 & 0 & $0-0.06$ & 5 & 0 & $0-0.25$ & 0.64 \\
\hline 23907 & ovarian abscess & 8 & 0 & $0-0$ & 7 & 0 & $0-0.25$ & $0 \cdot 18$ \\
\hline 3329 & blood & 10 & 0 & $0-0.03$ & 5 & 0 & $0-0.67$ & 0.43 \\
\hline 613 & wound & 10 & 0.06 & $0-0.13$ & 8 & $0 \cdot 10$ & $0-0 \cdot 16$ & 0.72 \\
\hline $\begin{array}{l}\text { All C. fetus } \\
\text { strains }\end{array}$ & & 37 & 0 & $0-0.05$ & 25 & 0 & $0-0 \cdot 25$ & 0.05 \\
\hline \multicolumn{9}{|l|}{ C. jejuni } \\
\hline 42734 & faeces & 10 & 0 & $0-0 \cdot 10$ & 6 & 0.94 & $0 \cdot 56-1 \cdot 00$ & 0.01 \\
\hline 43353 & faeces & 23 & 0 & $0-0.13$ & 11 & $0 \cdot 11$ & $0-0.29$ & $0 \cdot 10$ \\
\hline 39175 & faeces & 3 & 0 & $0-0.11$ & 5 & 0 & $0-0 \cdot 17$ & $1 \cdot 00$ \\
\hline 40630 & faeces & 12 & 0 & $0-0.12$ & 13 & 0 & $0-0 \cdot 21$ & 0.41 \\
\hline $\begin{array}{l}\text { All } C \text {. jejuni } \\
\text { strains }\end{array}$ & & 48 & 0 & $0-0 \cdot 11$ & 35 & $0 \cdot 11$ & $0-0 \cdot 30$ & 0.02 \\
\hline
\end{tabular}

Table III. The effect of a median dose of $2 \times 10^{9}$ campylobacters on the development of the 13-day mouse fetus

\begin{tabular}{|c|c|c|c|c|c|c|c|c|}
\hline \multirow{2}{*}{$\begin{array}{l}\text { Campylobacter sp. } \\
\text { and strain }\end{array}$} & \multirow[b]{2}{*}{ Origin } & \multirow{2}{*}{$\begin{array}{l}\text { Number } \\
\text { of mice }\end{array}$} & \multicolumn{2}{|c|}{$\begin{array}{l}\text { Proportion of resorptions } \\
\text { in control mice }\end{array}$} & \multirow{2}{*}{$\begin{array}{l}\text { Number } \\
\text { of mice }\end{array}$} & \multicolumn{2}{|c|}{$\begin{array}{l}\text { Proportion of resorptions } \\
\text { in infected mice }\end{array}$} & \multirow[b]{2}{*}{$\mathrm{p}$ value } \\
\hline & & & Median & IQR & & Median & IQR & \\
\hline \multicolumn{9}{|l|}{ C. fetus } \\
\hline 25320 & blood & 3 & 0 & $0-0$ & 10 & 0.32 & $0 \cdot 11-1 \cdot 00$ & 0.05 \\
\hline 23907 & ovarian abscess & 7 & 0 & $0-0$ & 4 & 0.63 & $0 \cdot 31-0.91$ & $0 \cdot 01$ \\
\hline 3329 & blood & 11 & 0 & $0-0$ & 17 & $1 \cdot 00$ & $0 \cdot 62-1 \cdot 00$ & 0.0002 \\
\hline 613 & wound & 20 & 0 & $0-0 \cdot 08$ & 19 & $0 \cdot 17$ & $0-0.70$ & $0 \cdot 007$ \\
\hline $\begin{array}{l}\text { All C. fetus } \\
\text { strains }\end{array}$ & & 41 & 0 & $0-0$ & 50 & 0.52 & $0 \cdot 11-1 \cdot 00$ & $<0.0001$ \\
\hline \multicolumn{9}{|l|}{ C. jejuni } \\
\hline 42734 & faeces & 10 & 0 & $0-0 \cdot 03$ & 9 & $1 \cdot 00$ & $0 \cdot 23-1 \cdot 00$ & $0 \cdot 002$ \\
\hline 43353 & faeces & 9 & 0 & $0-0$ & 10 & 0 & $0-0 \cdot 11$ & $0 \cdot 29$ \\
\hline 39175 & faeces & 4 & 0 & $0-0$ & 6 & 0.92 & $0.43-1.00$ & 0.04 \\
\hline 40630 & faeces & 8 & 0 & $0-0.09$ & 8 & 0 & $0-0 \cdot 16$ & $0 \cdot 60$ \\
\hline $\begin{array}{l}\text { All } C \text {. jejuni } \\
\text { strains }\end{array}$ & & 31 & 0 & $0-0$ & 33 & $0 \cdot 13$ & $0-1.00$ & 0.0007 \\
\hline
\end{tabular}


In a separate experiment the effects of heat-killed $C$. fetus and $C$. jejuni strains did not differ significantly from that produced by live bacteria (table IV).

\section{Clinical and bacteriological findings}

At no time throughout this series of experiments was any maternal illness noted, even though campylobacters could be isolated from the liver and spleen; in most instances, fewer than $10^{3} \mathrm{cfu}$ were recovered from each organ. Campylobacters were readily isolated from the resorbed placentae and resorbed fetuses of animals infected on day 13 of pregnancy. In an animal infected with $4 \times 10^{7} \mathrm{cfu}$ of $C$. fetus strain 23907 , one fetus alone yielded $4 \times$ $10^{5} \mathrm{cfu}$, and the corresponding placenta $2 \times 10^{6} \mathrm{cfu}$. However, no evidence of multiplication was noted in any tissue. Not all of the fetuses in the uterus were resorbed; normal, healthy fetuses could be seen interspersed between the resorbed conceptuses (fig. 1). A cross-section of a normal fetus and a resorbed fetus are shown in fig. 2.

\section{Discussion}

These experiments demonstrate that resorption of mouse embryos is readily induced by strains of both $C$. fetus and $C$. jejuni. This finding is similar to that made by Coid et al. (1978) and Coid (1976), who inoculated pregnant mice with live $E$. coli and with its purified lipopolysaccharide respectively. It seems possible, therefore, that the resorption in mice inoculated with campylobacters is caused by an endotoxin-like substance. Dennis (1959) and Naess and Hofstad (1984) demonstrated that $C$. fetus and $C$. jejuni possess lipopolysaccharide that is pyrogenic, antigenic and toxic for mice. Previously Naess and Hofstad (1982) suggested that the purified lipopolysaccharide of $C$. jejuni was similar to that from the family Enterobacteriaceae. Moreover, endotoxin-like activity has been shown in $C$. jejuni by Fumarola et al. (1982); this activity was, however, 4 to 8 times lower than that of $E$. coli.

There is a similarity between the effects of campylobacters and $E$. coli on 13-day pregnant mice, but the present experiments also demonstrated that at 6 days' gestation the campylobacters caused resorption of the fetuses, an effect not observed on the embryos of pregnant mice given an injection of $E$. coli endotoxin (Coid, 1976). This lack of effect of $E$. coli endotoxin on the 6-day fetus was attributed to the deficiency of vascular tissue, for which endotoxin appears to have a predilection (Zahl and Bjerknes, 1943), whereas in campylobac-

\section{Uterus from normal}

18-day pregnant mouse.

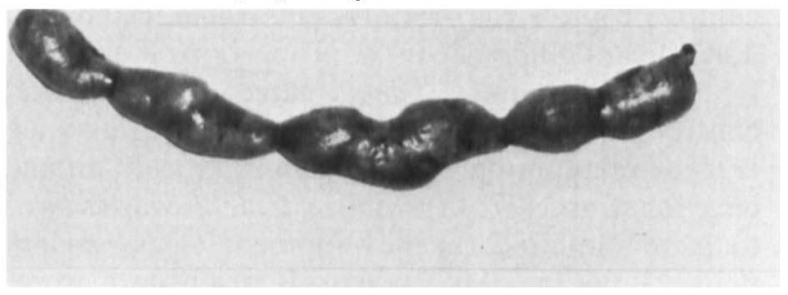

\section{Uteri from infected \\ 18-day pregnant mice.}

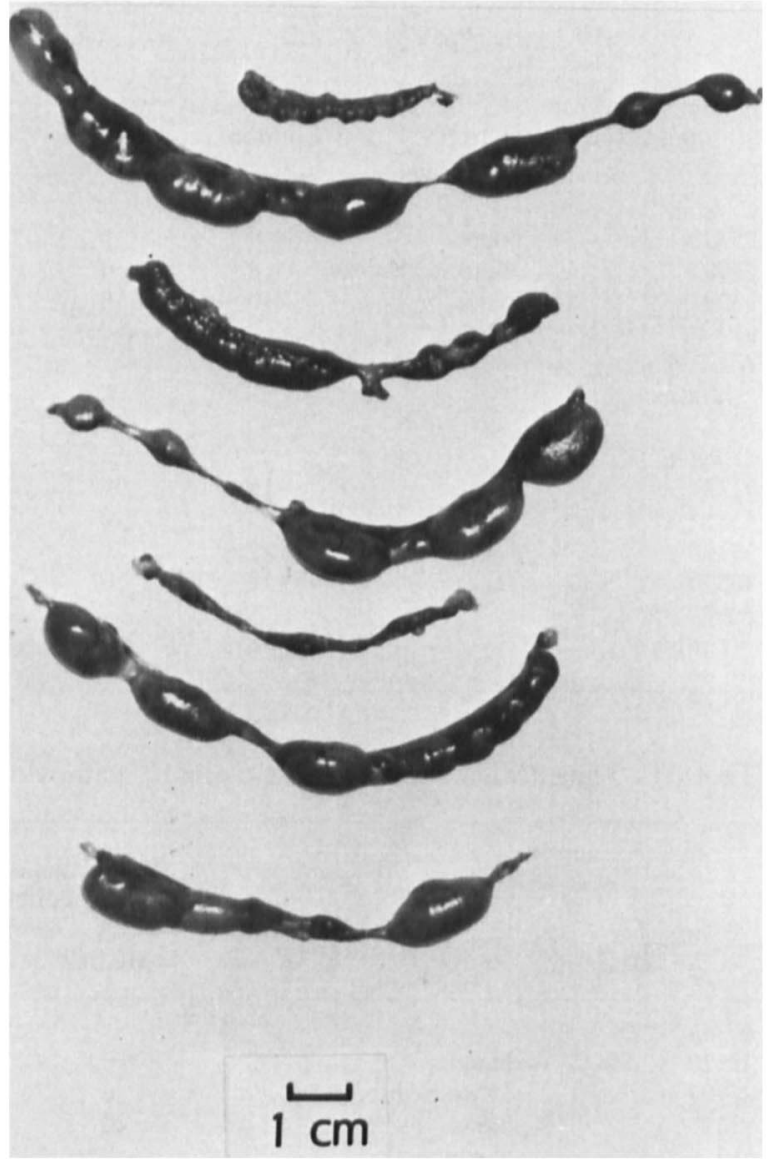

Fig. 1. Uterus from a normal mouse (18 days pregnant) and uteri from mice (18 days pregnant) given an intravenous injection of campylobacters on day 13 of pregnancy.

ter-infected mice the resorptions may have been a consequence of invasion of the fetus by live bacteria.

Effects similar to those described in this paper have been observed by Gasic and Gasic (1972) in the 6-day mouse embryo after injection of cholera 
Table IV. The effect of heat-killed campylobacters on the development of the 13-day mouse fetus

\begin{tabular}{|c|c|c|c|c|c|}
\hline \multirow[b]{3}{*}{ Campylobacter sp. } & \multicolumn{4}{|c|}{ Proportion of resorptions* produced by } & \multirow[b]{3}{*}{$\mathrm{p}$ Value } \\
\hline & \multicolumn{2}{|c|}{ living organisms } & \multicolumn{2}{|c|}{ heat-killed organisms } & \\
\hline & Median & IQR & Median & IQR & \\
\hline C. fetus & $0 \cdot 14(33) \dagger$ & 0 to 0.63 & $0(35)$ & 0 to 0.25 & 0.27 \\
\hline C. jejuni & $0 \cdot 25(35)$ & 0 to 1.00 & $0 \cdot 11(32)$ & 0 to 0.39 & $0 \cdot 15$ \\
\hline
\end{tabular}

* The results for all strains of each campylobacter species are combined.

$\dagger$ The numbers of mice inoculated are given in parenthesis.
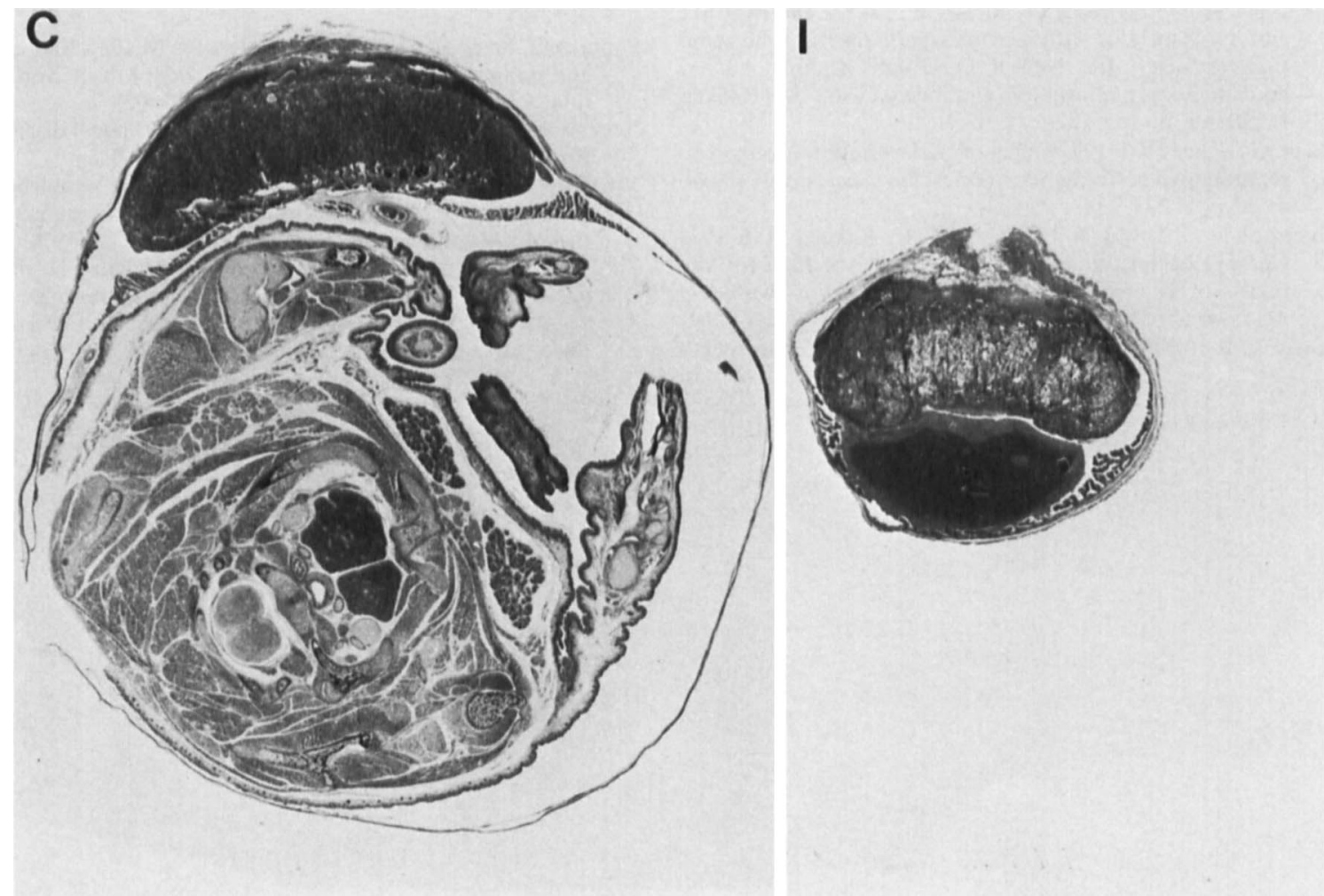

Fig. 2. Transverse section of a normal mouse (18 days pregnant) (C) and a mouse infected on day 13 of pregnancy with campylobacters (I). (Mag. $\times 8$ )

enterotoxin. They suggested that the interruption of gestation at this stage was not due to the passage of large amounts of toxin into the circulation, but to intense circulatory and metabolic changes resulting from heavy loss of body fluid from the mother.

In cattle it is well documented that $C$. fetus ss fetus causes infertility (Lawson, 1959; Morris and Park, 1971; Morgan and Wrathall, 1977). The present study shows that $C$. fetus also affects fertility in mice, by reducing the proportion of implants after injection into 2-day pregnant females; this again suggests the presence of a toxic substance having an effect on the pre-implanted embryo or on the uterus.

From these experiments in mice, it is apparent that campylobacters are capable of affecting the development of the fetus, and it seems probable that their pathogenic effects are due to substances similar to $E$. coli endotoxin and cholera enterotoxin.

We wish to thank Drs A. P. Johnson and S. Rastan for helpful advice and comments during the preparation of this paper. 


\section{REFERENCES}

Coid C R 1976 Bacterial endotoxin and impaired fetal development. Experientia 32: 735-736.

Coid C R, Fox H 1983 Campylobacters as placental pathogens. Placenta 4: 295-306.

Coid C R, Nicholson J 1981 The multiplication of three different isolates of Group B streptococci in pregnant mice. Placenta 2: $187-192$

Coid C R, Sandison H, Slavin G, Altman D G 1978 Escherichia coli infection in mice and impaired fetal development. British Journal of Experimental Pathology 59: 292-297.

Dennis S M 1959 Isolation of a lipopolysaccharide from Vibrio fetus. Nature 183: 186.

Dennis S M 1967 Mucinase activity of Vibrio fetus. Cornell Veterinarian 57 : 630-637.

Fumarola D, Miragliotta G, Jirillo E 1982 Endotoxin-like activity associated with heat-killed organisms of the genus Campylobacter. In: Newell D G (ed) Campylobacter: epidemiology, pathogenesis and biochemistry. MTP Press, Lancaster, pp 185-187.

Gasic G J, Gasic T B 1972 Effect of cholera entero-exotoxin on reproductive performance in mice. Immunological Communications 1 : 223-238.

Guerrant R L, Lahita R G, Winn W C, Roberts R B 1978 Campylobacteriosis in man: pathogenic mechanisms and review of 91 bloodstream infections. American Journal of Medicine 65: $584-592$.

Lawson J R 1959 Vibriosis. In: Stableforth A W, Galloway I A (eds) Infectious diseases of animals : diseases due to bacteria. Butterworths, London, pp 745-784.

Morgan W J B, Wrathall A E 1977 Aetiology, diagnosis, prevention and control of infections affecting pregnancy in farm animals. In: Coid CR (ed) Infections in pregnancy. Academic Press, London, pp 53-108.

Morris J A, Park R W A 1971 Metabolism of Campylobacter spp (Vibrio spp) in connection with pathogenicity and the use of neuraminidase to suppress pregnancy. Nature, 232: 132133.

Naess V, Hofstad T 1982 Isolation and chemical composition of lipopolysaccharide from Campylobacter jejuni. Acta Pathologica et Microbiologica Scandinavica, Section B 90: 135-139.

Naess V, Hofstad T 1984 Chemical composition and biological activity of lipopolysaccharides prepared from Type strains of Campylobacter jejuni and Campylobacter coli. Acta Pathologica et Microbiologica Scandinavica Section B 92: 217-222.

Simor A E, Karmali M A, Jadavji T, Roscoe M 1986 Abortion and perinatal sepsis associated with campylobacter infection. Reviews of Infectious Diseases 8: 397-402.

Skirrow M B 1977 Campylobacter enteritis: a "new" disease. British Medical Journal 2: 9-11.

Vinzent R, Dumas J, Picard N 1947 Septicémie grave au cours de la grossesse, due à un vibrion. Avortement consécutif. Bulletin de l'Academie Nationale de Medicine 131 : 90-92.

Zahl P A, Bjerknes C 1943 Induction of decidua-placental hemorrhage in mice by the endotoxins of certain gramnegative bacteria. Proceedings of the Society for Experimental Biology and Medicine 54: 329-332. 